\title{
QuAlity of Life AND ACTIVITY OF CHILDREN SufFERING FROM BRONCHIAL Asthma
}

\author{
A. Trzcieniecka-Green ${ }^{1}$, K. Bargiel-Matusiewicz ${ }^{2}$, A. Wilczynska-Kwiatek ${ }^{3}$ \\ ${ }^{1}$ Department of Psychology, Silesian Medical University, Katowice, Poland; ${ }^{2}$ Faculty of Psychology, Warsaw University, Warsaw, Poland; \\ ${ }^{3}$ Faculty of Psychology, Silesian University, Katowice, Poland
}

\begin{abstract}
Objective: The aim of this article was to analyze the quality of life of children suffering from bronchial asthma and to analyze their everyday activity.

Methods: The research was conducted in 137 children. The following questionnaires were used in the study: Pediatric Asthma Quality of Life Questionnaire (PAQLQ) and a questionnaire designed by the authors specifically for the purpose of the study.

Results: The findings of the study show that illness duration $(\mathrm{r}=-0.2 ; \mathrm{P}=0.22)$ and gender $(\mathrm{P}=0.37)$ do not influence the quality of life. It appears that among children ill with asthma a higher level of quality of life is typical for the children who live in the country side in comparison with those from cities $(\mathrm{P}<0.05)$. The comparison was also made in terms of everyday activity of children ill with asthma and non-asthmatic children. The children ill with asthma displayed less social contacts with peers/friends $(\mathrm{P}<0.05)$ and they performed less physical activities $(\mathrm{P}<0.05)$.

Conclusions: The study points to the possible beneficial effects of activating children's social interactions, creating conditions for appropriate development of their social competences, and of stress reduction connected with social interactions. Asthmatic children should also be encouraged to intensify appropriate physical activity.
\end{abstract}

Key words: bronchial asthma, quality of life

\section{INTRODUCTION}

The aim of this article is to analyze the quality of life and everyday activity of children suffering from bronchial asthma. Childhood is a period when many models of behavior - implemented later on in life are formed. Therefore, it is worthwhile to consider how children's chronic disease influences their evaluation of life quality and social activity $[1,2]$.

Civilization development and increase in environment pollution lead to an increase in the occurrence of allergic diseases, including bronchial asthma. WHO reports that 300 million people suffer from asthma worldwide. The International Study of Asthma and Allergies in Childhood (ISAAC) carried out in the 1990 s show that asthma affects $7.2 \%$ of children aged 6-7 and $11.3 \%$ of those aged 13-15. Progressive increase in the incidence of asthma makes this condition the most prevalent chronic disease of the respiratory system in children [3].
The disease, along its course, evokes varying emotions in children; the negative ones prevailing. Emotional disorders are experienced by $25-40 \%$ of asthmatic children; most often consisting of excessive psychological dependence on the parents and increased anxiety level [4]. Parents often tend to act incorrectly in such situations. They are overprotective, assume rigid attitudes, and get too much involved in other family members' lives. Overprotection impedes the child's emotional development, disturbs the development of self-reliance and independence. Excessive family concentration on the affected child leads to the lack of independence, egocentrism, and infantilism. The child starts to exert pressure on the family, whereas, when separated from the family, he is not self-confident and new situations trigger anxiety reactions [2]. Reducing everyday duties and permanent supervision of the child result in difficulties in adoption to living in the society $[5,6,7]$.

The child's chronic disease also may disturb the learning process. Difficulties at school may result from several factors, such as the medicines taken, the absenteeism due to disease exacerbation or hospitalizations. Oral glucocorticosteroids may disturb the cognitive processes or cause sleep disturbances, plaintiveness, anxiety, or depression. Beta2-adrenergic agonists, in turn, may cause muscles trembling and may be the reason for illegible handwriting. Sleepiness, decreased concentration, and fatigue are just some of the other side effects resulting from antihistaminic medicines.

Incorrectly controlled asthma, in its turn, or more severe forms of the disease may lead to lasting nightly complaints which, by disturbing child's sleeping, have an impact on both physical and mental functioning.

\section{MATERIAL AND METHODS}

The study protocol was approved by an institutional Ethics Committee. The following questionnaires were used for the study: Pediatric Asthma Quality of Life Questionnaire (PAQLQ) and a self-developed questionnaire addressed to both healthy and asthmatic children. The PAQLQ was used for the identification of negative physical, emotional, and social effects children suffering from asthma could be exposed to. The questionnaire enables to survey children aged 7-17. It consists of 23 items, including three domains: symptoms, emotions, and activity limitation. By summing 
up the score from these domains, a coefficient pertaining to the general quality of life $(\mathrm{QL})$ is obtained $[8$, 9].

Another tool was a self-developed questionnaire. It was directed to healthy children and children suffering from bronchial asthma. It is complementary with the PAQLQ. The goal is to gain information about everyday activity of children covered by the survey (contacts with age-mates, watching TV, time spent on using computer, reading books, physical activity) and to collect demographic data.

The survey was conducted on 137 Polish children from Katowice, Chorzów, Tarnowskie Góry and neighboring villages. There were 37 children suffering from bronchial asthma and 100 healthy children in the group. Children suffering from bronchial asthma, for whom at least a year had passed from the moment they were diagnosed with the condition, were selected to participate in the survey. There were slightly more girls in the whole group (52\%). However, girls made up $55 \%$ of the healthy children, whereas boys dominated among the asthmatic children (57\%). The youngest children in the survey were 7 and the oldest were 14 years old. The average age of the whole group was 10.6; it was 10.7 in the asthmatic children and 10.6 in the healthy ones.

\section{RESULTS}

Before calculations regarding the relation between the Quality of Life (QL) and other parameters were made, the results of the PAQLQ questionnaire had been verified. The aim was to define the relation between various results of individual sub-scales of this questionnaire (symptoms, emotions, and activity limitation) and the general result referred to as QL. To this end, coefficients of linear correlation were calculated between the results of sub-scales and the general result. As the correlations proved to be very strong (symptoms $\mathrm{r}=0.96$; emotions $\mathrm{r}=0.95$; activity limitation $\mathrm{r}$ $=0.94)$, it was assumed that the variables were actually univocal with the QL variable.

With reference to the above outlined, in further analyses, a comparison of the disease duration, place of living, and gender, on one hand, with the general result of PAQLQ, on the other hand, was made. Fig. 1 shows that there was a weak, negative correlation between disease duration and quality of life, which lacks statistical significance $(\mathrm{r}=-0.2 ; \mathrm{P}=0.22)$. Next, a relation between the place of living and QL was analyzed. For this purpose, the significance of differences in QL assessed by children living in the city and in the country was statistically verified. The results are presented in Table 1. It was found that in the case of children suffering from bronchial asthma, the children living in the country assessed their QL higher than those living in the city.

Further, the relation between the gender and QL was analyzed. These results, presented in Table 2, show that the differences in QL between girls and boys suffering from bronchial asthma were statistically irrelevant.

Finally, everyday functioning of children suffering from bronchial asthma and their age-mates was evaluated. The comparison encompassed the following: how much time was spent on different activities reading books, watching TV, meeting friends (after school), time spent for computer games, and physical activities. The results of this comparison are presented in Table 3.

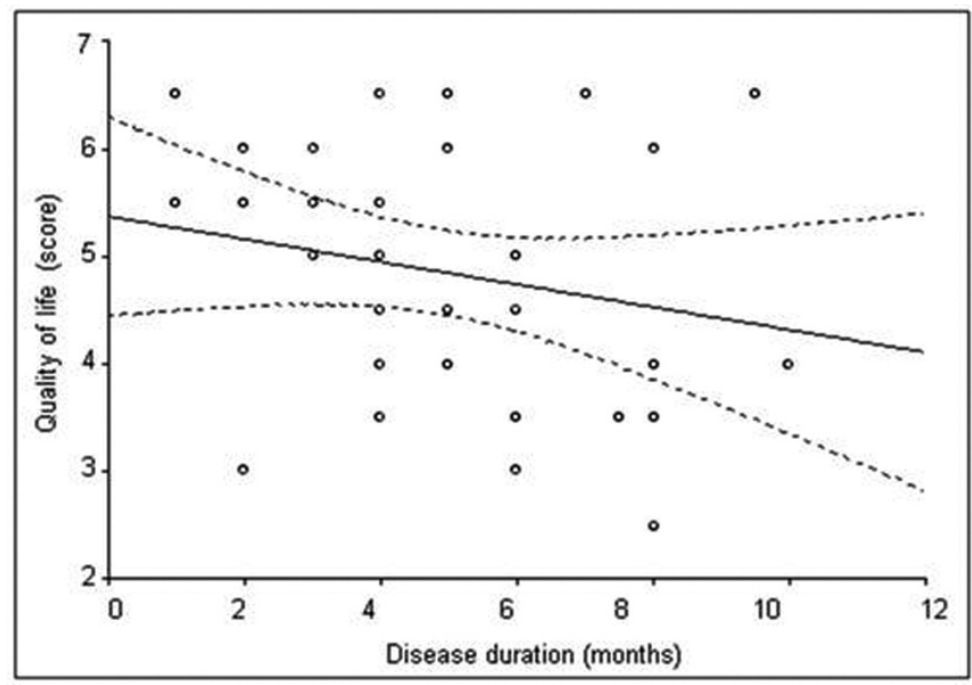

Fig. 1. Relation between the duration of disease and quality of life.

Table 1. Differences in Quality of Life (QL) of children living in the city and in the country.

\begin{tabular}{lllll}
\hline Sum of ranks - QL in the city & Sum of ranks - QL in the country & U Statistics & $\mathrm{P}$ & $\mathrm{n}$ \\
\hline 262.5 & 440.5 & 72.5 & $<0.05$ & $\begin{array}{l}\text { City 19 } \\
\text { Country 18 }\end{array}$ \\
& & & & \\
\hline
\end{tabular}

QL - quality of life; Mann-Whitney-U test. 
Table 2. Significance of differences between Quality of Life (QL) of girls and boys.

\begin{tabular}{lllll}
\hline Sum of ranks - QL among girls & Sum of ranks - QL among boys & U Statistics & P & n \\
\hline 369.5 & 333.5 & 138.5 & P = 0.37 & $\begin{array}{l}\text { girls 21; } \\
\text { boys 16 }\end{array}$
\end{tabular}

QL - quality of life; Mann-Whitney-U test.

Table 3. Comparison of physical activities of healthy children and children suffering from bronchial asthma.

\begin{tabular}{llllllll}
\hline & $\mathrm{n}$ & $\%$ & $\begin{array}{l}\text { Reading books } \\
(\mathrm{min})\end{array}$ & $\begin{array}{l}\text { Watching TV } \\
(\mathrm{min})\end{array}$ & $\begin{array}{l}\text { Meeting friends } \\
(\mathrm{min})\end{array}$ & $\begin{array}{l}\text { Computer } \\
\text { (min) }\end{array}$ & $\begin{array}{l}\text { Physical activities } \\
\text { (min) }\end{array}$ \\
\hline $\begin{array}{l}\text { Healthy children } \\
\text { Asthmatic children }\end{array}$ & 100 & 73 & 52 & 113 & 117 & 112 & 144 \\
\hline
\end{tabular}

Table 4. Significance of differences concerning the time spent with friends.

\begin{tabular}{lllll}
\hline Sum of ranks - Asthmatic Children & Sum of ranks - Healthy Children & U Statistics & $\mathrm{P}$ & $\mathrm{n}$ \\
\hline 1344.5 & 8108.5 & 641.5 & $\mathrm{P}<0.05$ & $\begin{array}{c}\text { Asthmatic }-37 \\
\text { Healthy }-100\end{array}$ \\
\hline
\end{tabular}

Mann-Whitney- U test.

Table 5. Significance of differences concerning physical activities.

\begin{tabular}{lllll}
\hline Sum of ranks - Asthmatic Children & Sum of ranks - Healthy Children & U Statistics & $\mathrm{P}$ & $\mathrm{n}$ \\
\hline 1721.0 & 7732.0 & 1018.0 & $\mathrm{P}<0.05$ & $\begin{array}{l}\text { Asthmatic }-37 \\
\text { Healthy }-100\end{array}$ \\
\end{tabular}

Mann-Whitney- U test.

The differences concerning the average time devoted for reading books, watching TV, and using computers in asthmatic vs. healthy children were insignificant. Yet, remarkable statistical differences were found with reference to the average time spent with friends after school and that devoted to physical activities (117 vs. $35 \mathrm{~min}$ for social interaction and 144 vs. $81 \mathrm{~min}$ for physical activities in healthy and asthmatic children, respectively). Statistical elaboration of these results is presented in Tables 4 and 5.

\section{DisCUSSION}

The present study failed to substantiate the existence of significant relationships between gender of children suffering from asthma or the duration of disease and their quality of life. The lack of such relationships is in accord with other studies on the subject [5]. What turned out to be significant was the relation between the place of living and quality of life of asthmatic children. It was found that children living in the country assessed their quality of life better than those from the city. A better assessment of quality of life among country children may result from a few factors, such as a slower pace of life, less pressure of time, and therefore less associated stress. Children living in the coun- try spend more time with their parents who give them more support. They may also be supported by their grandparents, who live in common households much more often than in case of cities. Another reason for a feeling of a better quality of life in these children may be less polluted natural environment in the country, which in case of asthma directly translates to the frequency of respiratory symptoms.

Concerning everyday functioning of children, the analysis shows that both asthmatic and non-asthmatic children spend a comparable amount of time on reading books, watching TV, and using computer. Yet, a significant difference appeared concerning the time spent on socializing with friends after school. Healthy children tend to spend remarkably more time with their friends than the asthmatic ones, on average, 117 min vs. $35 \mathrm{~min}$, respectively. Thus, it seems to be important to encourage children suffering from asthma to intensify social activity, to engage in contact with age-mates, and to do so not only at school, but also after classes. Proper social relations constitute an essential factor in the process of forming the self-assessment and the sense of self-efficacy, which are of crucial meaning for functioning in many areas of life [1, 7]. Beside, there is a risk that a child who spends little time with age-mates will experience much more stress 
in the situations of social interactions than persons for whom social contacts are something normal in everyday functioning. Many authors claim that stress and negative emotions can trigger and exacerbate the symptoms of asthma $[2,10,11]$. It is worth mentioning that sanatorium treatments have a positive influence on social skills. Staying in this kind of facilities allows establishing new friendships, and therapeutic classes not only develop new skills, but also allow overcoming emotional stresses often accompanying the disease. Contact with other children suffering from bronchial asthma allows sharing one's experiences with others and to find out about the way others deal with the condition.

There also was a significant difference concerning physical activity between asthmatic and healthy children to the disadvantage of the sick; on average, 81 vs. 114 min, respectively. Admittedly, it is a detrimental occurrence and may result from incorrect convictions of parents or teachers, and passed onto children, that physical activity should be shunned or disadvised in asthma, due either to reduced children's capability or the possibility of asthma aggravation. Research shows that doing sports by people suffering from asthma, under appropriate pharmacological umbrella, reduces bronchial hyperreactivity and improves physical efficiency. However, not every sport discipline is recommended to children suffering from asthma. Due to high minute ventilation, they should avoid such sports as basketball, cycling racing, long-distance races, or other high-performance sports. Exposure to cold and dry environment while doing sports is not recommended either. What is recommended are the disciplines where effort is spread over time, e.g., swimming, riding a bike, gymnastics, or canoeing. The diagnosis of bronchial asthma does not mean at all that a child should lead sedentary life and resign from the benefits of physical activity. Activity is not only a perfect way to be in a good shape, enjoy good health, but also to keep good mental condition (12). Previous research shows that what is essentially important concerning physical activity is the perceived competence at it and attitude toward it (14). Therefore, it is crucial to help shape positive attitude toward physical activity in children with asthma.

In summary, the present survey may help shape attitudes toward functioning of children suffering from asthma. Such children should be encouraged to the interactions on social level, which would create conditions for appropriate development of their social competences and to reduce stress connected with such interactions. They also should be encouraged to intensify physical activity taking into account recommendations as to the forms of activity suitable for these children.
Conflicts of interest: The authors reported no conflicts of interest in relation to this article.

\section{REFERENCES}

[1] Janion E. Zaspokajanie potrzeb psychicznych dzieci przewlekle chorych. Problemy Opiekunczo - Wychowawcze 2000; 1: 32-35 (Article in Polish).

[2] Lehrer P, Feldman J, Giardino N, Song H, Schmaling K. Psychological aspects of asthma. J Consul Clin Psychol 2002; 70: 691-711.

[3] Asher MJ, Weiland SK. The international study of asthma and allergies in childhood. Clin Exp Allergy 1998; Suppl 28: $52-66$

[4] Trojanowska A, Bernat K. Funkcjonowanie emocjonalne a wiedza o chorobie dzieci chorych na astme oskrzelowa. Zdrowie Publiczne 2002; 112: 192-194 (Article In Polish).

[5] Adamska R, Drózdz Z, Breborowicz A, Pawlaczyk B. Zmienne spoleczno - ekonomiczne a jakosc zycia dzieci z astma oskrzelowa. Pielegniarstwo Polskie 2005; 2: 294 299 (Article in Polish).

[6] Bray M, Theodore L, Patwa S, Margiano S, Arlic J, Peck H. Written emotional expression as an intervention for asthma. Psychol Sch 2003, 40, 193-207.

[7] Bray M, Kehle T, Peck H, Theodore L, Zhou Z. Enhancing subjective well-being in individuals with asthma. Psychol Sch 2004, 41, 95-100.

[8] Juniper E. Pediatric Asthma Quality of Life Questionnaire. Ontario, McMaster University Medical Center, 1999.

[9] Adamska R, Drózdz Z, Breborowicz A, Pawlaczyk B. Wykorzystanie kwestionariusza PAQLQ w badaniu jakosci zycia dzieci z astma oskrzelowa. Pielegniarstwo Polskie 2005; 19: 22-26 (Article in Polish).

[10] Milton B, Whitehead M, Holland P, Hamilton V. The social and economic consequences of childhood asthma cross the life course: a systematic review. Child Care Health Dev 2004; 30: 711-728.

[11] Ritz T, Steptoe A, DeWilde S, Costa M. Emotions and stress increase respiratory resistance in asthma. Psychosom Med 2000; 62: 401-412.

[12] Welsh L, Kemp J, Roberts R. Effects of physical conditioning on children and adolescents with asthma. Sports Med 2005; 35: 127-141.

[13] Pianosi P, Davis H. Determinants of physical fitness in children with asthma. Pediatrics 2004; 113: 225-229.

Corresponding author:

Kamilla Bargiel-Matusiewicz

Faculty of Psychology

Warsaw University

Stawki 5/7 St.

00-183 Warsaw, Poland

Phone: +48 225549703

E-mail: K.matusiewicz@op.pl 